\title{
Egy bútoripari cég gyártásütemezése során fellépő nehézségek döntéstámogatása
}

\section{Decision Support for Difficulties in a Furniture Manufacturing Company}

\author{
K. BAKON ${ }^{1}$, T. HOLCZINGER ${ }^{2}$ \\ 1Pannon Egyetem Nagykanizsai Kampusz, Alkalmazott Informatikai Tanszék, bakon.krisztian@uni-pen.hu \\ 2Pannon Egyetem Nagykanizsai Kampusz, Alkalmazott Informatikai Tanszék, holczinger.tibor@uni-pen.hu
}

Kivonat: „Egy bútoripari cég gyártásütemezése során fellépő nehézségek döntéstámogatása” című munkánk során bemutatásra kerül egy konkrét bútoripari cég múködése és a múködése során tapasztalt nehézségek, melyeket valamilyen módon igyekeznek elhárítani, hogy a cég múködését ezek ne akadályozzák. Ezek után bemutatásra kerül, hogy milyen módon kívántuk elérni a termeléstervezés támogatásához készített rendszert. Különböző verziók szerint részletezve, hogy aktuálisan milyen célt kívántunk elérni, miközben olyan eredményeket mutatunk, amelyek jól szemléltetik a rendszer fejlődését. Továbbá érintjük a fejlesztés nehézségeit, mely Java nyelven készült el. A rendszer fejlesztése során elért utolsó verzió és az általa készített eredmények is bemutatásra kerülnek. A rendszer alkalmassá vált a bemeneti paraméterek feldolgozása után olyan ütemezési algoritmusok felhasználásával eredményt készíteni, mely a termeléstervezés során fontos döntések meghozatalakor segíthetnek.

Kulcsszavak: Java, termeléstervezés, ütemezés, gyártás

Abstract: In "Decision support for difficulties in a furniture manufacturing company" titled work we are presenting in detail the operation of a particular furniture company and the difficulties encountered during its operation, which they try to overcome in some way so that they do not hinder the operation of the company. After that, we will show how we wanted to achieve the production support system. In different versions, we detail what we actually wanted to accomplish while showing results that illustrate the evolution of the system. We also present the difficulties of the development, which is made in Java. We also present the latest version of the system and its results. After processing the input parameters, the system is able to produce results using scheduling algorithms that can help in making important decisions during production planning.

Keywords: Java, production planning, scheduling, production

\section{Bútoripari cég bemutatása}

A cég elsődleges termékei minőségi ülőgarnitúrák, de a palettájukba tartoznak még franciaágyak, étkezőpadok, székek, fotelek és ülőkék is. A cég nem kizárólag a magyar vevők igényeit igyekszik kielégíteni, hanem közel 20 export célországba is gyártanak bútorokat. Céljuk nem csupán az 
értékesítési és vevői igények kielégítése, de hogy elnyerjék partnereik bizalmát is. Továbbá fejlesztéseik eredményeként a régió egy jelentős tényezőjeként további növekedést szeretnének elérni, hogy a nemzetközi piacokon is hasonlóan jelentős szereplőként tűnjenek fel. A cég rendelések alapján állítja össze a termeléshez szükséges terveket. Bár több alvállalkozó is bedolgozik nekik, most csak a cég belső működését szeretnénk bemutatni, amit az alábbi ábra jól szemléltet:

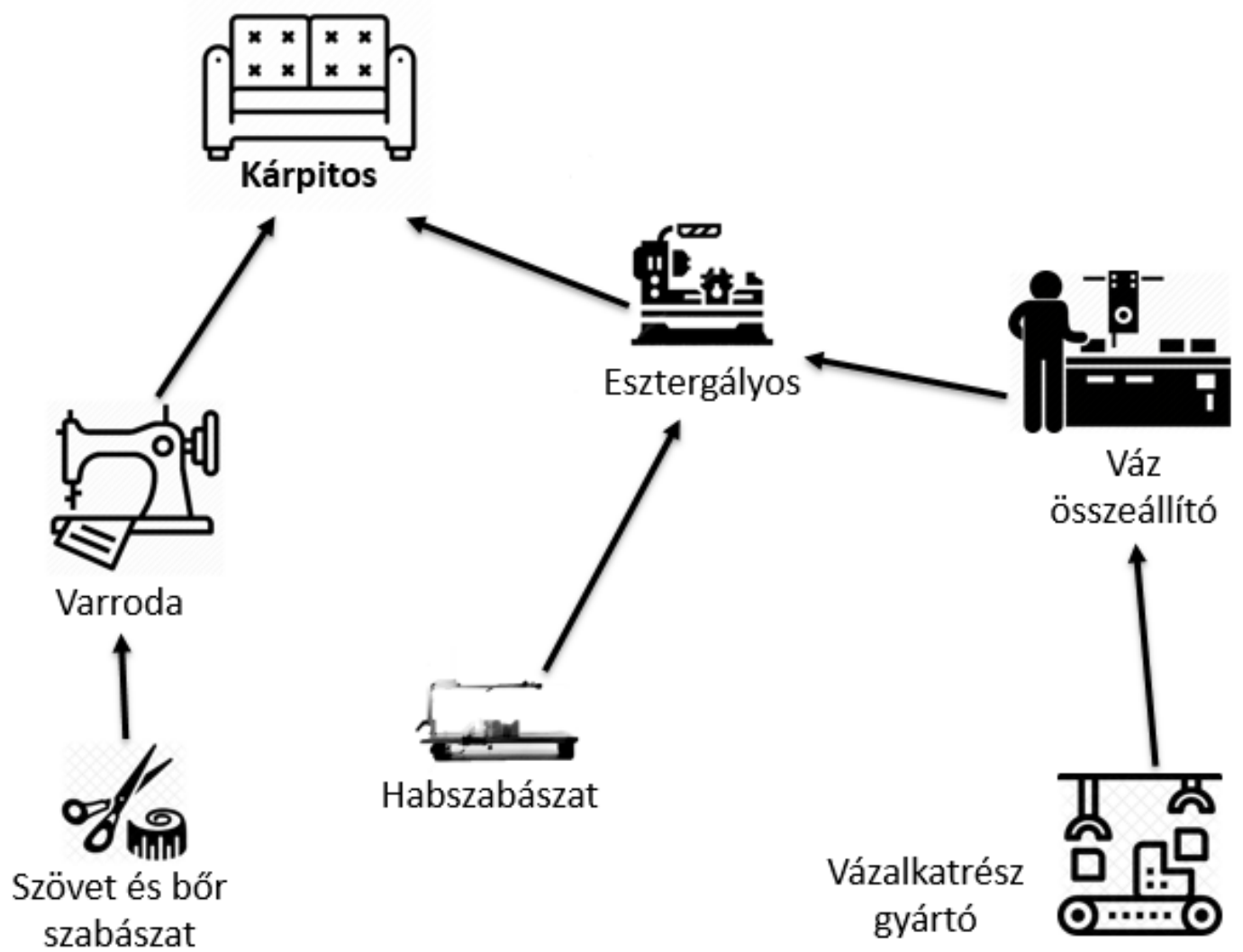

1. ábra. Bútorcég üzemei és kapcsolatuk

Ahogy az 1. ábrán is látható, több üzem is részt vesz a késztermék előállításának elérése érdekében. Ahogy korábban említettük, a cég rendelések alapján tervezi a gyártási folyamatait. Ezen rendelések fogadása után előfeltételek alapján készítik elő a tervezéshez, melyeket elsősorban a szabad kapacitás és a nyersanyagok rendelkezésre állása határoz meg. Ezek teljesülése esetén kezdődhet meg maga a gyártási folyamatok tervezése, melyhez szükséges az üzemek pontos összehangolása. Egyik oldalról a vázalkatrészgyártó üzemben elkészítésre kerülnek a késztermék vázához szükséges elemek, amelyet elsősorban az alapanyagok felhasználásával készítenek el és csak utána rendezik össze azokat a csomagokat, melyek majd az adott termék előállításához szükségesek. Ezen csomagok bekerülve egy vázösszeállítóba, összeállításra kerülnek a kiadott termék tervei alapján, így megkapva a késztermék vázát, melyet majd fel kell tölteni. Emellett a habszabászatban a termék belsejét kitöltő hab alapanyag méretre szabása és előkészítése után a belső tartalom és a váz kerül egyesítésre az esztergályos üzem által. Másik oldalon a termék külsejét befedő szövet és/vagy bőr szabászata kerül elvégzésre, amelyet szintén a rendelkezésre álló alapanyagokból szabnak méretre az adott termékhez megfelelően, majd ezután a varrodában összeállításra kerülnek ezek, mely így képes lesz a termék külső arculatát meghatározó alakot betölteni. Végül a különböző szálak találkoznak a kárpitos üzemben, ahol minden részalkatrész összeállításra kerül. A folyamat készülhet gyártósorhoz hasonló részfeladatokra bontással is, de bizonyos termékeknél csupán egyhelyben áll a leendő késztermék, melyet egy vagy több szakember állít össze. 


\subsection{Kárpitos üzem termeléstervezése}

Az egész rendszer tervezésének legfontosabb pontjának mondható a terveléstervezés. Az összes üzem megegyezik a terveléstervezés első feltételében, azaz minden üzem a kárpitos üzem termeléstervezéséből, pontosabban annak programozásából indul ki, amikor a saját termeléstervezésüket kezdik meg.

A kárpitos termeléstervezése több szempontot kell figyelembe vegyen. Kiindulásként kezdjük a szerződésekkel, melyeket a vevőkkel kötnek. Több, a gyártáshoz tartozó adat is innen kerül kiolvasásra, mint például az adott termék típusa, mennyisége, a rendelés teljesítését meghatározó határidő, továbbá egyéb, a termékre értendő információk, melyek a késztermékre vonatkoznak. A különböző terméktípusokat gyártási kulcsokkal jelölnek, ahol átmenetek is vannak, azaz az adott terméktípus adott gyártási kulcshoz való rendelése az alap eljárás, ám több gyártási kulcs közötti átmenet azt jelenti, hogy amelyik termék az egyik kulcshoz tartozik, attól még a termék gyártását el lehet végezni másik gyártási kulcson futó összeszerelés során is. Vannak továbbá olyan szerződések, melyek valamely okból kifolyólag nagyobb prioritást élveznek. Ezen prioritások is több szintet tartalmaznak, melyekből csak az első, azaz a legfontosabbak vannak jelölve a rendszerben. A többi prioritási szint már nem aktualizált dokumentumokban található, így a termelést tervező szakemberek emlékezetére kell hagyatkozni, ha az ehhez hasonló döntést meg kell hozni. Ezeket az információkat a szakember más területeken dolgozó munkatársak közötti kommunikációval szerzi be. Ezt bővíti az a szempont is, hogy bizonyos termékeket nem lehet ütemezni ugyanarra a napra - a feladat elvégzéséhez szükséges eszközök hiánya miatt melyen információkat a tervezést végző személy emlékezetből és hiányos dokumentumokból szerez be és állít össze.

Újabb szempont a termelés tervezés során az adott termék alapanyagszükségletének kielégítése, amelyet az alapanyagraktár tart számon. Némi nehézséget okoz azonban ennek az információnak a karbantartása, ugyanis a vállalatirányítási rendszer bár lehetőséget ad a hiányos alapanyagok megjelölésére, azt mégsem használják. Ennek oka, hogy ha a termeléstervezés a kapott információk alapján megjelöli, mint hiányt - hogy a további tervezési lépések során ne kerüljenek megjelenítésre azon rendelések, amelyek teljesítéséhez szükséges alapanyagok nem állnak rendelkezésre -, akkor a raktár feladata az alapanyag megérkezésekor ezt az állapotot a rendszerben megváltoztatni. Ez a tevékenység gyakran elmaradt, mivel a raktár az új alapanyagot bár bejegyzi, de nem fér hozzá a termeléstervezés során megjelölésre kerülő alapanyagok bejegyzéséhez, így azt nem tudja feloldani a tiltó listáról. Emiatt az lett a bevett gyakorlat, hogy a termeléstervezést folyamatos kommunikációval értesíti az alapanyagraktár, ha valamely alapanyagra hiány lép fel, illetve, ha a hiány orvoslásra került. Ezt enyhíti az a folyamat, hogy a tervezés megkezdésekor adott alapanyag hiánya be van jelezve, de ha napközben ez az állapot megváltozik, úgy ezt az információt nem azonnal frissítik a rendszerben.

A szempontok bővülnek az adott nap termeléskapacitásának mértékével, mely nem állandó. Egy termék elkészültéhez valamilyen közös mértékegységben meg kellett állapodni, mely a perc lett, amit a rendelt terméktípus elkészítésének időszükséglete és a rendelésben szereplő mennyiségek határoznak meg. A tapasztalatok azt mutatták, hogy a hét elején a munkavállalók morálja nem ér el kellő szintet, így alacsony a munkakedv, ezért az aznapi kapacitáslimit is alacsony (8000 perc). A hét közepén viszont pont ellenétes a tapasztalat, azaz akkor a legnagyobb a munkakedv, ami miatt arra a napra lehet a legnagyobb idejű (12000 perc) tervezést elkészíteni. A hét végére természetesen újra alábbhagy a munkakedv, így hasonló eredményt kapunk, mint a hét elején, a fennmaradó napokon pedig átlagosnak 
tekinthető. Az alábbiakban a munkakedvet nem érdemes szó szerint értelmezni, inkább munkateljesítményt kell alatta érteni, de a specifikációban meghatározott leírástól nem kívántunk eltérő szóhasználattal élni. A kapacitáskorlátoktól el lehet térni kis mértékben, maximum 10\%-ban, aminek a kihasználása nagyban függ az előző napi feladatok maradéktalan elvégzésétől (vagy történt-e csúszás), illetve az adott napon az emberi erőforrásban fellépő hiánytól és hogy a fennmaradó erőforrás maradéktalanul el tudja végezni a feladatokat.

Megkötése a tervezésnek, hogy a termelésprogramozás megvalósítása után azon változtatni nem lehet, mivel a programozott ütemezés szerint készíti el a többi üzem a saját termelésprogramozását. Ezt erősíti az a folyamat is, hogy az alkatrészgyártás során az alapanyagokat maradéktalanul dolgozzák fel, ami sok esetben túlteljesíti a kárpitos üzem által kiadott igényeket.

\section{Gyártástervezést támogató rendszer}

Az előző fejezetben bemutatásra került az a cég, ahol a különböző folyamatokba bepillantást nyerhettünk és sok nehézséget sikerült feltárni. Célunk ezen nehézségek enyhítése oly módon, hogy az általunk elkészített rendszer segítségével zökkenőmentesen tudjanak haladni minden feladattal akkor is, ha a továbbiakban nem a már bejáratott és megszokott folyamatokat, hanem a mi eredményeinket alkalmazzák. A feladat egy olyan rendszer megvalósítása, ami az előző fejezetben bemutatott szempontokat figyelembe véve a megfelelő adatok megadásával automatikus feldolgozást követően adjon olyan eredményt, melyet a kárpitos üzem termeléstervezése tud hasznosítani. Reményeink szerint ezzel a részleg hatékonysága jelentősen növekszik és a feladatok időszükséglete csökken, ezáltal olyan kapacitások szabadulnak fel, melyeket hasznosíthatnak további elavult és kockázatos folyamatok feltárására és azok javítására, optimalizálására.

\subsection{Forrás adatok}

Első lépésként a cég által nyújtott rendelési adatokat kellett elemezni, minden értéknek a jelentését megvizsgálni a cégnél töltött idő során átvett tapasztalatok segítségével és olyan irányban kellett elindulni, aminek az eredményét későbbi feltételekkel bővítve lehet finomítani.

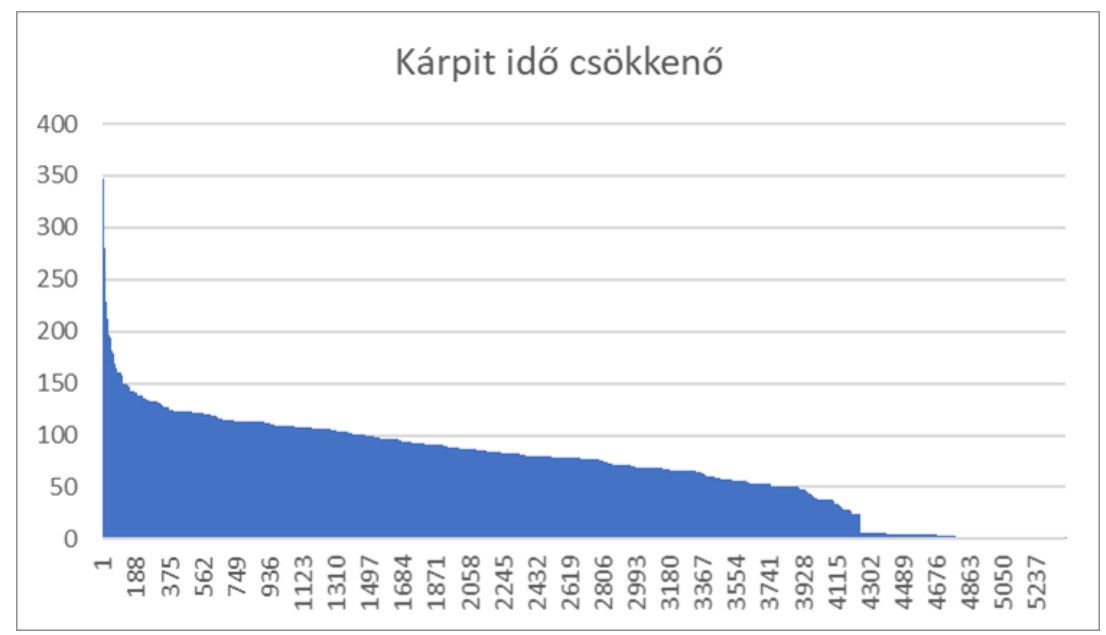

2. ábra. Rendelések a kárpitos idő szerint csökkenő sorrendben

A 2. ábrán látható diagram azt szemlélteti, hogy a rendelési adatokból kinyert kárpitos üzemre vonatkozó időtartam mekkora, vagyis egy feladatnak mekkora időszükséglete van. A szemléltetés 
kedvéért csökkenő sorrendbe lettek rendezve, hogy jól láthatóvá váljon az a problémát okozó ok, amibe a munkánk során többször is belefutottunk. Ez pedig a különböző feladatok időszükségletében lévő szélsőséges érték. Látható, hogy a diagram is kiemelkedő értékről kezd, míg a végén nagyon alacsony értékeket mutat. A pontosság kedvéért a diagram 5409 feladatot mutat, azon belül azok időszükségleteit. A sorba rendezésre azért van szükség, mert a munka során elsősorban a lista és az LPT algoritmust használtuk fel, utóbbi esetében pedig az első lépés a kapott feladatok időrendben csökkenő sorrendbe való rendezése. Rengeteg szempontot figyelembe kell venni ahhoz, hogy a rendszer a kapott adatokat megfelelően tudja feldolgozni, minden feltételt megfelelően kezeljen és ezek mind megjelenjenek a kapott eredményeken. A korábbi fejezetben ismertetve lett, hogy ezen feltételek forrása nem minden esetben megbízható, illetve olyan módon változik, melyet nem minden esetben lehet lekövetni. Emiatt az első lépésekben a rendszer a feltételek kis részét veszi csak figyelembe, hogy az így kapott eredmény helyességét könnyebben lehessen ellenőrizni és utólag kis lépésekben történő feltételbővítés során lehessen pontosítani rajta.

\subsection{Első verzió}

Az adatok sok információval rendelkeztek, ám ahhoz, hogy a rendszer lefutása után is minden feladat könnyen azonosítható maradhasson, új adatokkal kellett bővíteni azokat. Az adatokat Excel táblázatban kaptuk meg, melyet először fel kellett dolgozni, hogy a rendszer megfelelően tudja tárolni a további műveletek elvégzéséhez. Miután ez megtörtént, implementálni kellett a fő algoritmust, ami a feladatokat az adott gépekhez rendeli. Ebben a kontextusban szeretném kiemelni, hogy a gép kifejezés alatt nem konkrét gyártási gépet szeretnék képviselni, hanem az adott műszak gyártósorainak típusát jelképezik. Ehhez a gépeket is létre kellett hozni és az egyszerűség kedvéért biztosítani kellett, hogy a gépek kezdetben 0 töltöttséggel rendelkezzenek. Miután megtörtént az adatok kiolvasása, feldolgozása és a gépek előkészítése, az algoritmus lefutásával képesek voltunk a gépekhez rendelni a feladatokat. Ám ez így önmagában nem volt elegendő, ugyanis így a megadott számú gépek között osztja szét az összes feladatot. Ezért be kellett vezetni egy újabb feltételt, amellyel az adott nap kapacitásának felső korlátját határoztuk meg, így azt elérve az algoritmus nem rendel több feladatot az adott nap gépeihez. Ha egy nap összes gépe elérte a maximum kapacitást a kapott feladatokkal, akkor a rendszer tovább lép a következő napra, újból elkészíti és biztosítja az adott nap gépeit, figyelembe véve azt is, hogy mely napot vesszük figyelembe és az adott naphoz tartozó kapacitáskorlátot használja a végrehajtás során. A rendszer miután végzett, újból Excel táblázatba menti a kapott adatokat, amik olyan eredményt mutatnak, melyeket szeretnék bemutatni.

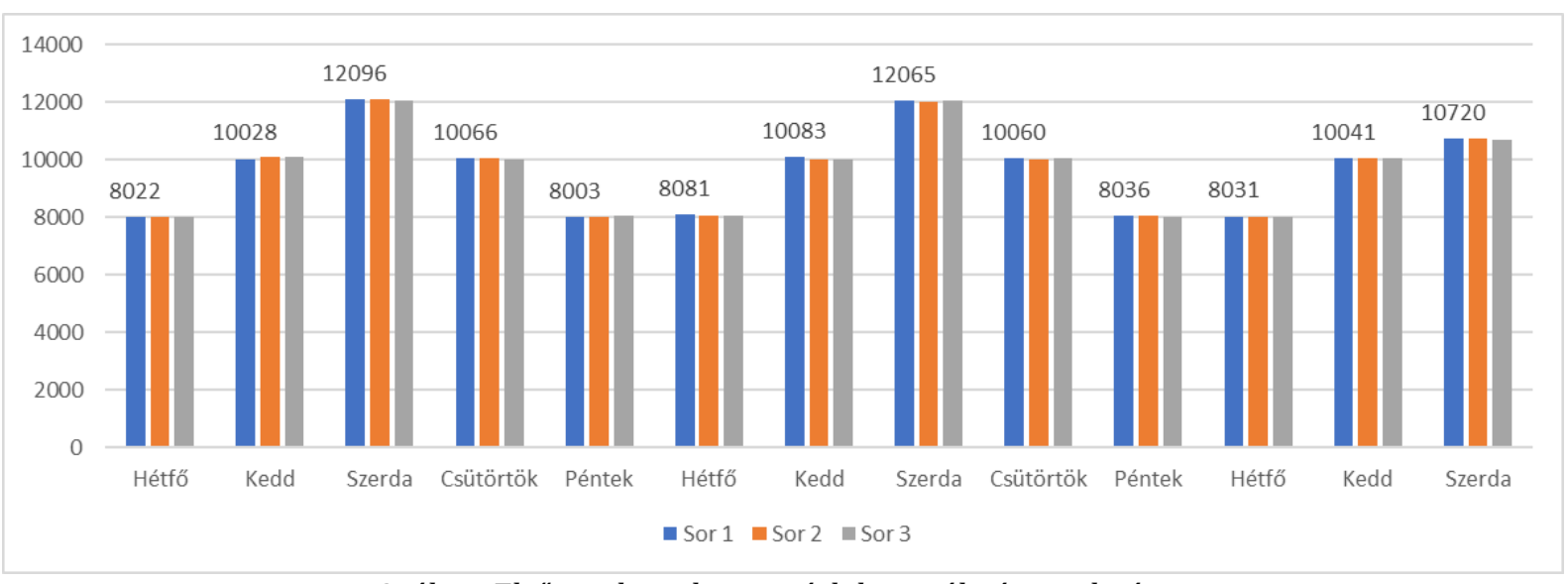

3. ábra. Első rendszer kapacitáskihasználtság eredménye 
A 3. ábra azt az eredményt szemlélteti, hogy a kapott feladatokat szétosztva az adott napok gépei között milyen módon sikerült az adott naphoz tartozó kapacitáskorlátot elérni. Látható, hogy ezesetben három gépet, azaz gyártósortípus került előkészítésre. Az adott nap gépéhez rendelt feladat továbbra is lekövethető maradt, tehát ha rámutatnak egy adott feladatra, hogy mely nap mely gépen lesz elvégezve, úgy azt könnyen meg lehet továbbra is határozni. Ezen ábra utolsó napját azért nem érdemes figyelembe venni, mert addigra elfogytak a feladatok, ezért nem éri el a szükséges kapacitást. Látható az is, hogy a gépek töltöttsége a maximális kapacitás ellenére minden esetben meghaladja azt. Ennek az az oka, hogy megengedhető némi eltérés a korláttól (maximum 10\%), de azt biztosítani kell, hogy 100\% legyen a gép kihasználtsága. Többet mond a kapott eredményekről a következő ábra.

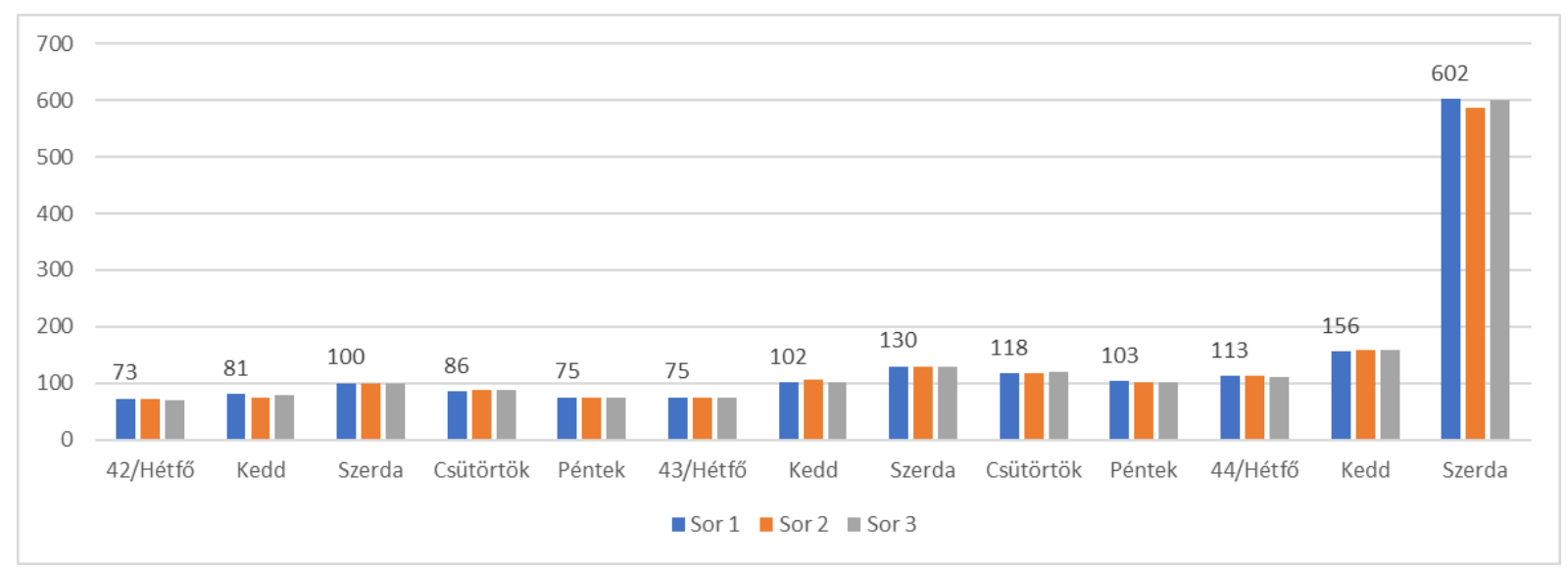

4. ábra. Első rendszer feladatkiosztás számának eredménye

A 4. ábrán a feladatok szétosztása a napokon belül a gépek eredményét mutatja, azon belül is azt, hogy mennyi feladatot rendelt egy adott napon egy adott géphez. Ha összevetjük a 3. és 4. ábrát, láthatjuk, hogy míg a 3. ábrán az utolsó nap eredményekor nem érte el a szükséges kapacitást egyik gép sem, mivel elfogytak a feladatok, addig a 4. ábrán az utolsó nap esetén az látható, hogy drasztikusan nőtt a feladatok száma. Ennek az LPT algoritmus első lépéseként megtett csökkenő sorrendbe rendezése az oka. A 2. ábrán látható volt, hogy szélsőségesen nagy vagy kicsi lehet az időszükséglete bizonyos feladatoknak, melyek száma nem elhanyagolható, így azt az eredményt kaptuk, hogy az utolsó napon rendelte a gépekhez a legkisebb időszükséglettel rendelkező feladatokat, melyek száma így túl magasra nőtt. Egy napon egy gép alatt értett gyártósortípuson 602 darab feladat elvégzése meglehetősen kétséges végeredményt okozhat, tekintettel arra, hogy a korábbi napokon ennek a számnak kevesebb mint az ötödét kellett elvégezni a gyártósortípusokon.

\subsection{Második verzió}

A fentebb bemutatott problémára igyekeztünk új megoldást készíteni, ám ehhez a rendszer átalakítása vált szükségessé. Eddig röviden összefoglalva annyit tett a rendszer, hogy a feladatlistát idő szerint csökkenő sorrendbe rendezte, majd a feladatokon egyesével végig haladva szétosztotta az adott nap gépei között. Miután végzett az adott nappal, váltott a következő napra és megismételte az eljárást, mindezt addig, amíg el nem fogytak a feladatok. A változtatást azzal kezdtük, hogy a korábbi algoritmus mellett még egyszer meghívásra került az algoritmus egy módosított változata, mely a feladatokat időben nem csökkenő, hanem növekvő sorrendbe rendezte, majd ez alapján rendelte a gépekhez őket. Ez esetben viszont nem az eddig megadott kapacitást vette figyelembe, hanem egy új változóval bevezettünk extra kapacitást, ami az addig megállapított kapacitásra került, azt tovább növelte. Ám 
újabb problémába ütköztünk, melyet szintén meg kellett oldani. Mivel a feladatok sorrendje így változott, ezért azt is meg kellett oldani, hogy a már a gépekhez rendelt feladatokat ne vegye újból figyelembe. Ezen okból kifolyólag a rendszer működése a következő. Csökkenő időrendi sorrendbe rendezi a rendelkezésre álló feladatokat, elkészíti előre a gépeket, melyek töltöttsége nulla, majd az adott naphoz tartozó kapacitást figyelembe véve a gépekhez rendeli a feladatokat. Miután ez megtörtént, megvizsgálja a rendszer mely feladatokat kapták meg a gépek, összegyűjti őket és a kiosztatandó feladatlistából ezeket eltávolítja, hogy ne forduljon elő feladat duplikálás. Ezt követően a második, módosított algoritmus kerül lefutásra, mely a még rendelkezésre álló feladatokat növekvő sorrendbe rendezi, majd a már napi kapacitást elérő telített gépek kapacitását megnöveli egy adott értékkel, és amíg nem éri el az új maximális kapacitást az adott gép, addig rendel hozzá további feladatokat. Miután ezzel végzett, ismételten megvizsgálja a rendszer, mely feladatok lettek a gépekhez rendelve, ezeket összegyűjtve végez egy összehasonlítást a feladatok listájával és amelyek már a gépekhez lettek rendelve, azon feladatokat törli a feladat listából. Ezzel a rendszer végzett az adott nap gépeinek feladattal való feltöltésével, elmenti az így kapott eredményt, vált a következő napra és annak tulajdonságait figyelembe véve újra megkezdi az egész műveletet. Ezt addig folytatja, amíg van rendelkezésre álló feladat.

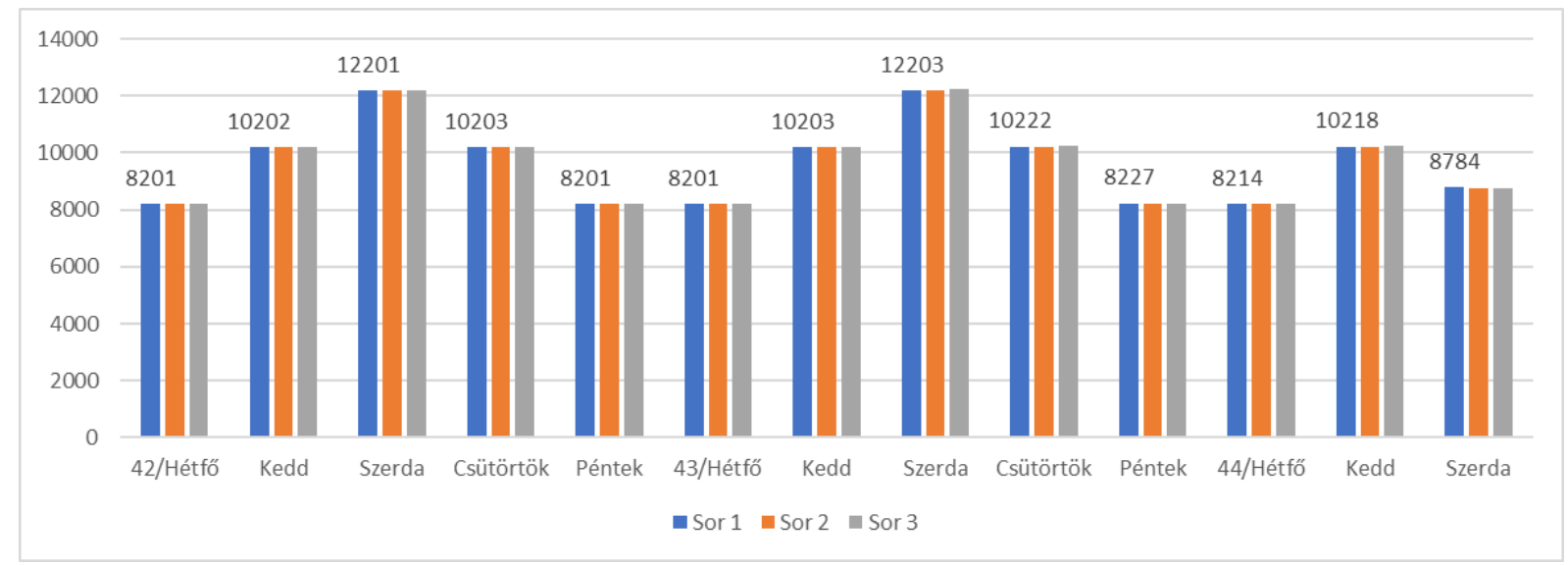

5. ábra. Második rendszer kapacitáskihasználtság eredménye

A 5. ábrán látható a fent levezetett rendszer múködésének eredménye, azon belül is az, hogy miképp lett az adott napokhoz tartozó gépekhez rendelve minden feladat. Úgy, mint az első rendszer eredményénél, úgy itt se érdemes figyelembe venni az utolsó napot, mivel addigra elfogytak a feladatok. A 3. és 5. ábrát összehasonlítva azt a különbséget láthatjuk, hogy a napok maximális kapacitása mindkét esetben teljes, de az értéke eltér. Ez annak az eredménye, hogy alacsony mértékben lett meghatározva az extra kapacitás, aminek az értéke ebben az esetben 200, ami még bőven a maximálisan megengedhető kapacitáskilengési határon belül van minden nap esetében. Ebből a szempontból látható, hogy a rendszer továbbra is megfelelően végzi a feladatát, azaz teljes kapacitáskihasználtságot értünk el. 


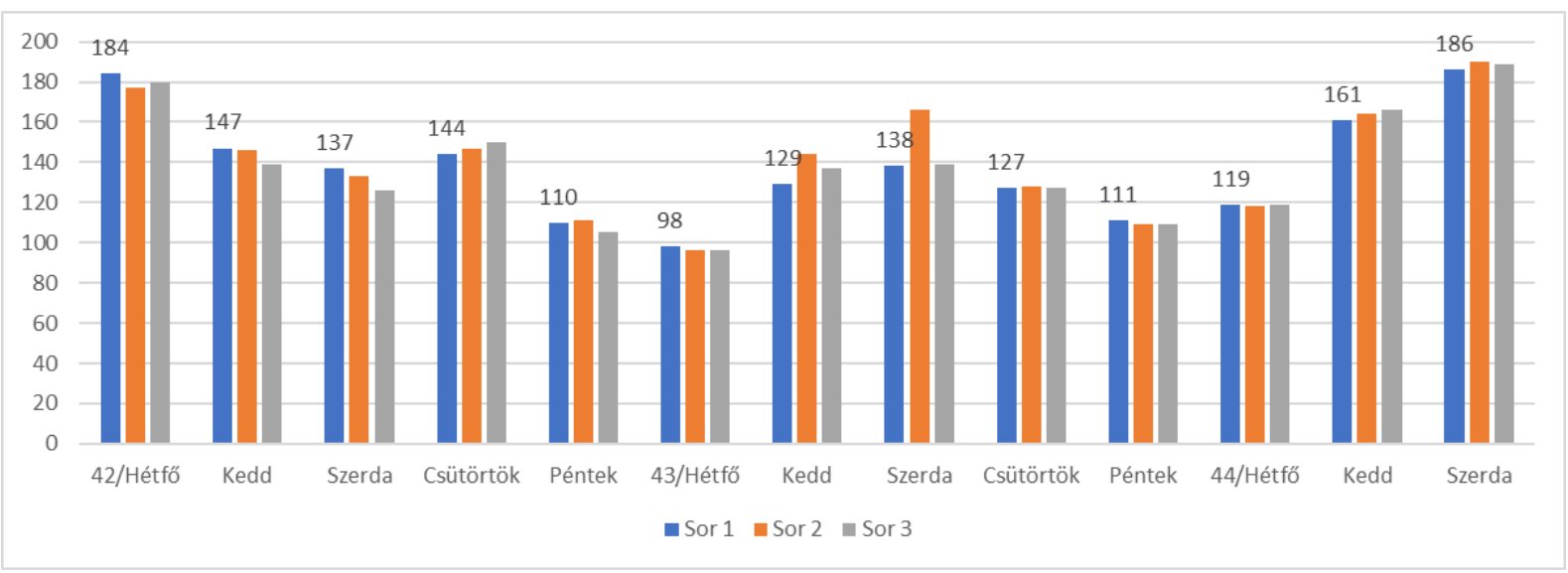

6. ábra. Második rendszer feladatkiosztás számának eredménye

A 6. ábrán látható eredmény a feladatok adott napon adott gépekhez történő rendelését mutatja abból a szempontból, hogy melyik gép pontosan mennyi feladatot kapott. Mivel a maximális kapacitás ki lett bővítve 200-zal, így nem az utolsó napra kerültek a legkisebb teljesítési idővel rendelkező feladatok, hanem folyamatosan lettek rendelve minden napon minden géphez. Megállapíthatjuk, hogy a korábban bemutatott probléma jelenleg már nem áll fenn, mivel az utolsó nap feladatszáma nem kiugróan magas. Némi kilengést azért hordoz magával a rendszer, mivel több olyan nap is látható az eredményen, ahol a gépek közötti feladatszámok között nem elenyésző különbségeket lehet felfedezni. További anomália, hogy a rendszer ezekkel a módosításokkal bár megoldotta a korábbi problémát, most viszont az első nap feladatszáma növekedett meg a szokásostól eltérően magasabbra. Némi módosítást lehet eszközölni a rendszeren, ha elégedetlenek vagyunk az eredménnyel, mivel a maximális kapacitást azzal az új bevezetett változóval, mellyel ezt tovább növeljük a megadott értékkel, ezen érték módosítható. Több tesztelés után ezekkel a feladatokkal a 150-200 intervallumon lévő értékek vezettek a legjobb eredményekre.

Újabb módosítást eszközöltünk a rendszeren, mivel az eddigi eredmények elérték azt a pontot, amire azt mondhattuk, hogy jók lettek. Az új módosításra azért volt szükség, mert a korábban ismertetett adatokból is kitűnik, hogy nem megfelelő az elvárásoknak a jelenlegi rendszer múködése. Ezt az okozza, hogy eddig a feladatok ideje volt figyelembe véve és hallgatólagosan egy feladat egy darabot jelentett. A kapott adatokban viszont van külön mennyiségi tényező is, amit figyelembe véve azt kapjuk, hogy egy feladat elvégzésének időszükséglete a feladat időszükséglete szorozva a feladat mennyiségi értékével. 


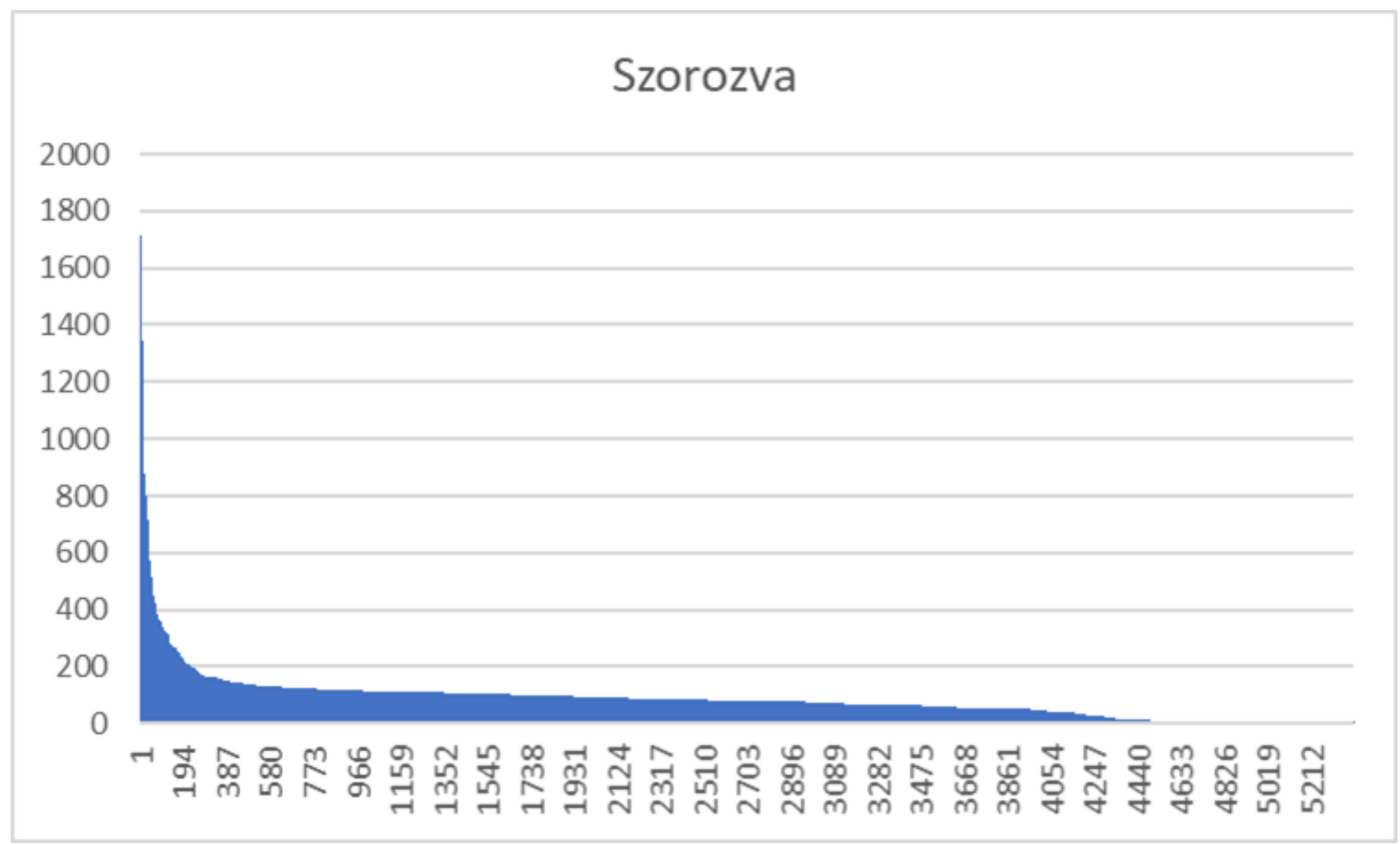

7. ábra. Rendelések a kárpitos idő szerint csökkenő sorrendben a mennyiség figyelembevételével

A 7. ábrán a feladatok idejét kívántuk szemléltetni, ahol a mennyiséget is figyelembe vesszük. Összehasonlítva a 2. ábrán látható eloszlással, kitűnik, hogy sokkal nagyobb lett a két szélsőséges oldal közötti különbség, azaz a nagy időszükséglettel rendelkező feladatok időszükséglete drasztikusan megnőtt, amihez képest a kevesebb, vagy nagyon alacsony időszükséglettel rendelkező feladatok időszükséglete alacsony maradt. Ebből arra lehet következtetni, hogy az eddig működő rendszer ezekkel a módosításokkal már nem fogja hozni a kívánt eredményeket.

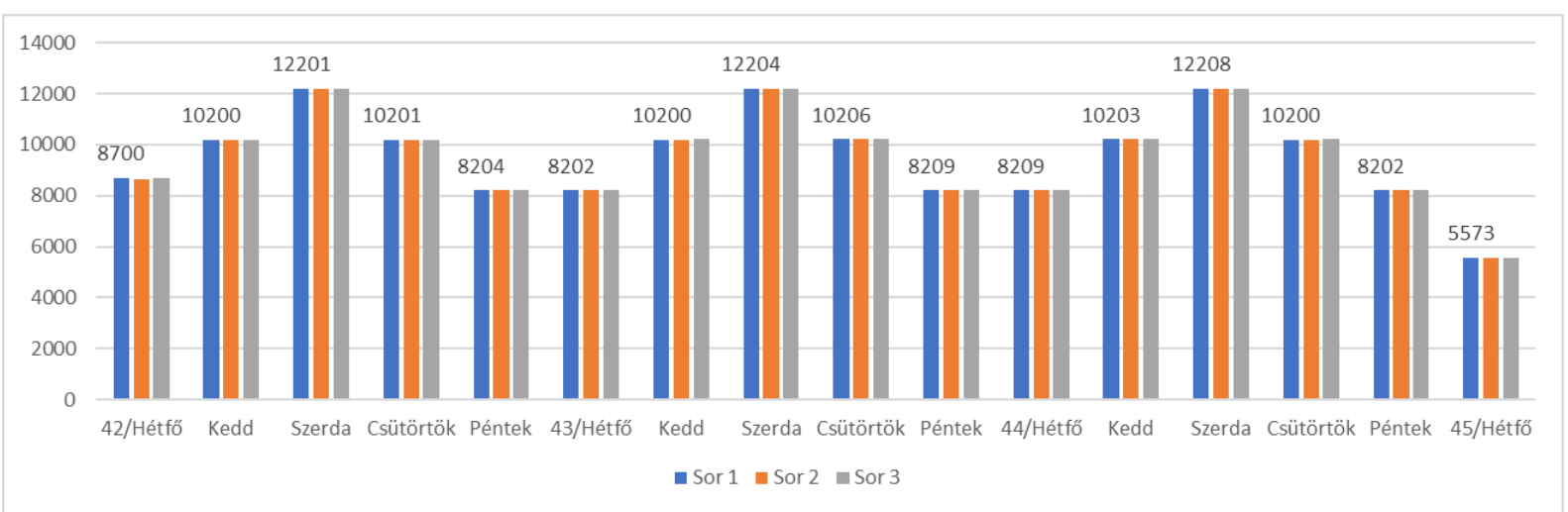

8. ábra. Második rendszer kapacitáskihasználtság eredménye mennyiséggel együtt

A 8. ábrán az új rendszer lefutása utáni eredményt láthatjuk a kapacitáskihasználtság szemszögéből. Ezek az eredmények nem mutatnak túl nagy különbséget az előzőkéhez képest azt leszámítva, hogy ebben az esetben három munkanappal bővült a feladatok elvégzéséhez szükséges munkanapok száma, de az utolsó napot leszámítva minden nap kapacitáskihasználtsága teljes. 
DOI: $10.21791 /$ IJEMS.2020.1.34

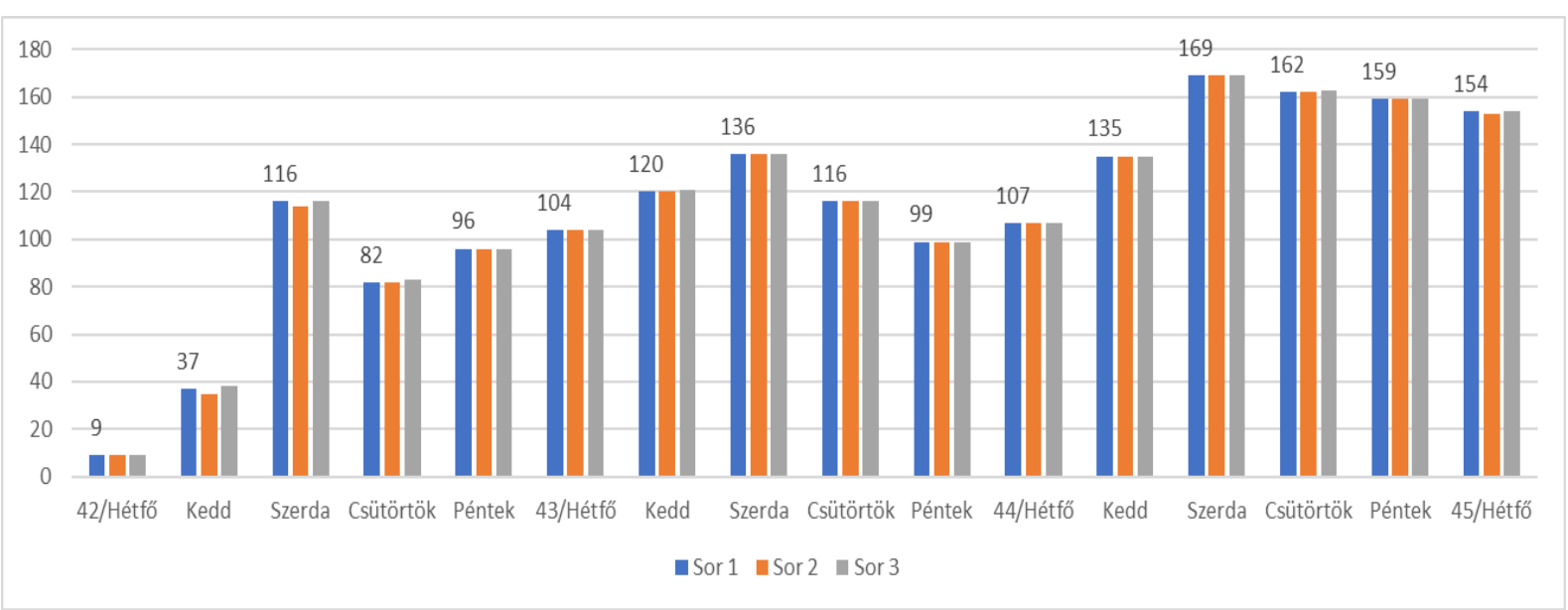

9. ábra. Második rendszer feladatkiosztás számának eredménye mennyiséggel együtt

A 9. ábra a feladatkiosztások számának szemszögéből mutat eredményt. A korábban ismertetett maximális kapacitás továbbra is ki van bővítve ez esetben szintén 200-as értékkel. A feladatok eloszlása a napok között nem mutat túl nagy mértékbeli eltérések, ám ezesetben az első és talán a második nap kivétel. Az első nap meglepően alacsony feladatszáma azon okból kifolyólag következik, hogy a 7. ábrán látható volt, hogy a mennyiség bevezetésével még inkább megugrott bizonyos feladatok elvégzéséhez szükséges idő. Ez olyan fokú időszükséglet növekedést eredményezett, hogy igazából pár feladat elvégzése betölti a teljes napot az adott gyártósortípuson. Mivel a feladatok száma mögötti mennyiségi értékek nem láthatók, így ezen eredmény nem mondható teljes mértékben hibásnak, továbbá a korábban megfogalmazott célt eléri a rendszer, így készen áll a további módosításra.

\subsection{Utolsó verzió}

Eddig a rendszer egy nap feladatlistáját készítette el az összes géphez rendelve a feladatokat a maximális kapacitást figyelembe véve. Mivel a korábban felvetett problémák bizonyos szinten megmaradtak, így más módon kellett ezeket kezelni. Ehhez az a cél lett kitűzve, hogy a rendszer a feladatok kiosztásakor ne egy adott napra levetítve végezze el, hanem egy egész hetet vegyen kiindulási alapnak és a héten belüli napoknak rendelje ki a feladatokat. Első lépésként elő kellett készíteni mind az 5 naphoz tartozó összes gépet, meghatározva a különböző napokhoz tartozó különböző maximális kapacitáskorlátokat. Miután ez elkészült, a rendszer elkezdhette a feladatát. Első lépésében a feladatokat sorrendbe rendezi a gyártási idő és a határidők figyelembevételével. Azaz, olyan feladatlistát kapunk, ahol hetekre osztva rendezi a feladatokat, azokon belül pedig az elvégzéshez szükséges idő szerint csökkenő sorrendben kezdi el a feladatok kiosztását. Ezután először megvizsgálja a soron következő feladat gyártási kulcsát, majd az alapján kezdi el keresni a megfelelő nap gépét. Ekkor azalapján választ, hogy a hét napjai közül mely a legkevésbé telített. Ahhoz, hogy ez a keresés megfelelő eredményt adjon, azt is figyelembe kellett venni, hogy a különböző napok különböző maximális kapacitás korlátokkal vannak ellátva és amikor a legkisebb kapacitáskorláttal rendelkező nap telítettsége elérte a maximumot, akkor azt a napot már ne vegye figyelembe és a többi nap között keresse a legkisebb telítettséggel rendelkezőt. A feladatok kiosztása akkor tekinthető késznek, ha már minden nap elérte a maximális kapacitáskorlátját. Miután a rendszer végzett az adott héttel, elmenti az eredményeket és a még nem kiszervezett feladatok listájából kivonja a már gépekhez rendelt feladatokat. Ezután a módosított algoritmus kerül lefutásra, ahol a feladatok listája a gyártáshoz szükséges idő szerint kerülnek növekvő sorrendbe, hogy a kis időszükséglettel rendelkező feladatok is elosztásra kerüljenek és ne az utolsó hétre maradjanak. A 
következőkben bemutatott eredmények a másodlagos algoritmus során a maximális kapacitás kibővítésére használt érték 200.

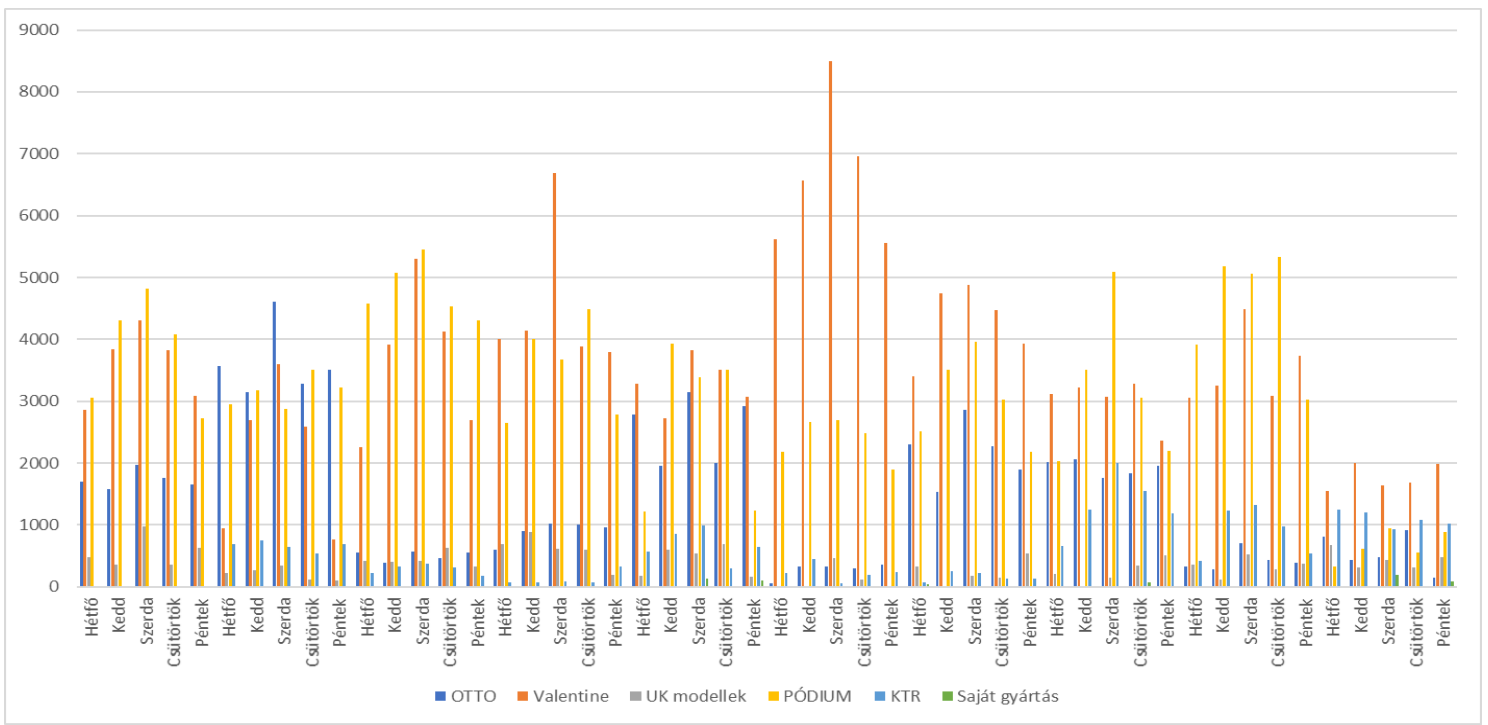

10. ábra. Utolsó rendszer kapacitáskihasználtság eredménye

A 10. ábrán látható, hogyan kerültek elrendezésre a feladatok és miként lettek elérve a napokra meghatározott maximális kapacitások. Mivel a rendszer már egy egész hétre rendezi a feladatokat, nem napokra, így a korábbiaktól eltérően nem csak az utolsó napot, de az utolsó hetet sem érdemes figyelembe venni, mivel addigra az elvégzendő feladatok elfogytak. A korábbi verzióhoz képest kiugróbb értékeket lehet felfedezni, de ez minden hétre jellemző.

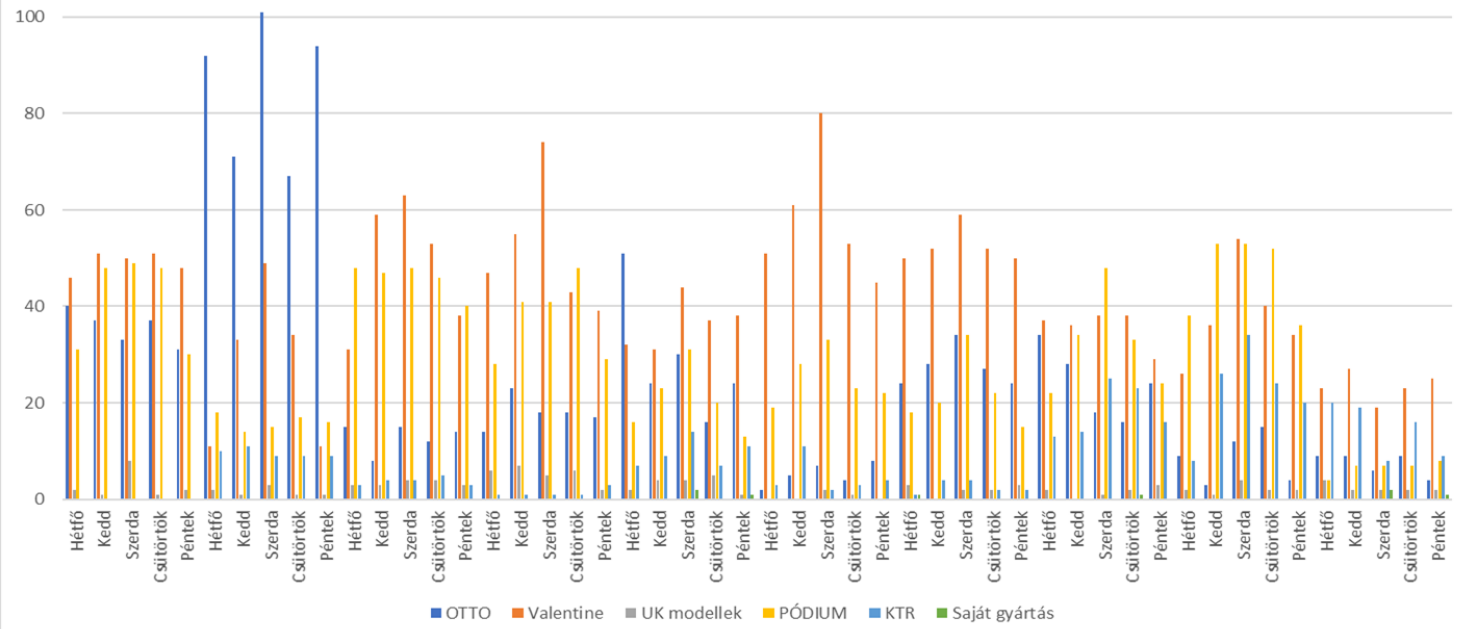

11. ábra. Utolsó rendszer feladatkiosztás számának eredménye

A 11. ábrán a feladatkiosztások számát tekinthetjük meg. A korábban jelentkező probléma - az utolsó napon vagy az első héten magas feladatszám - eltűnni látszik. Bár az első héten megemelkedett a feladatok száma, ám a többi hét napjainál is előfordul ez az eset, így nem néhány napra kerül a csak magas számú feladat teljesítése. Összevetve a 10. és 11. ábrát, az első hét eredményei azt mutatják, hogy a kis időszükséglettel rendelkező feladatok kerültek kiosztásra. Ez okozza az eltéréseket, nevezetesen, hogy az időszükséglet szerinti eredmény esetén a „PÓDIUM” rendelkezik a legmagasabbal, míg a feladatok számának eredményénél ugyanebben az időben az „OTTO” rendelkezik a legmagasabbal. 
Mivel a másodlagos algoritmus során meghatározott érték 200 - a korábbi tapasztalatok megfelelő eredményeket adtak erre az értékre - ezért feltételeztük, hogy ezúttal nem megfelelő már. Több próbálkozás eredménye során sem sikerült jelentős eltérést elérni, ezért arra a következtetésre jutottunk, hogy a másodlagos algoritmust nem futtatjuk és az elsődleges algoritmus (LPT) elején elvégzett sorba rendezések esetén csak a gyártási hét szerintit végzi el a rendszer, a kárpitos üzem időszükségletét nem, hogy a bemeneti paraméter sorrendjében végezze el feladatát a rendszer.

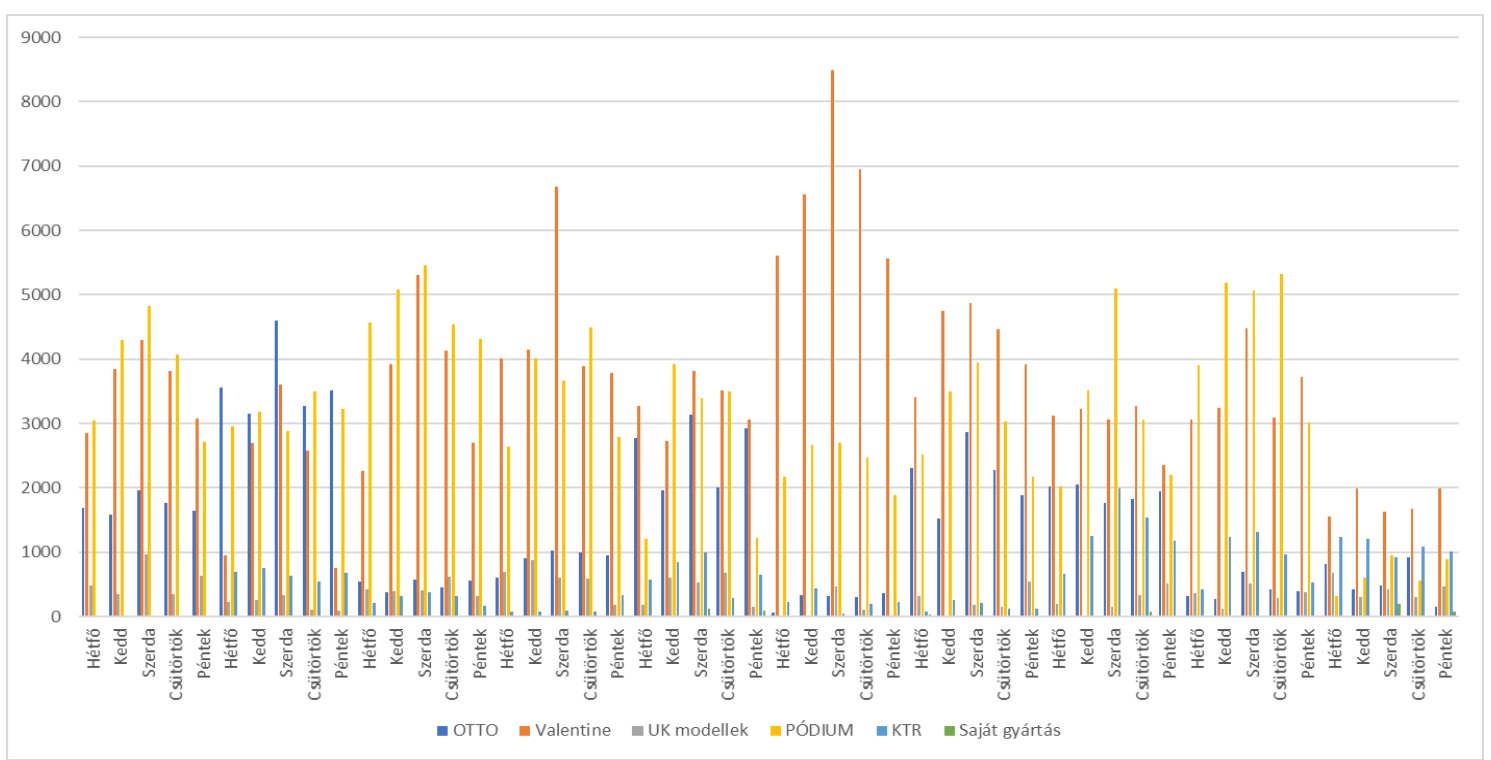

12. ábra. Utolsó rendszer kapacitáskihasználtság eredménye Lista algoritmussal

A 12. ábra első ránézésre megfelelő eredményeket hozott. Ám ha összevetjük a 10. ábra eredményeivel, hátható, hogy az első hét során tapasztalható kiemelkedő érték, mely a „PÓDIUM” gyártósor típushoz tartozott, Lista algoritmus használata esetén nem kiugró, sőt, majdhogynem a „Valentine” gyártósor típus eredményeivel egyenlő.

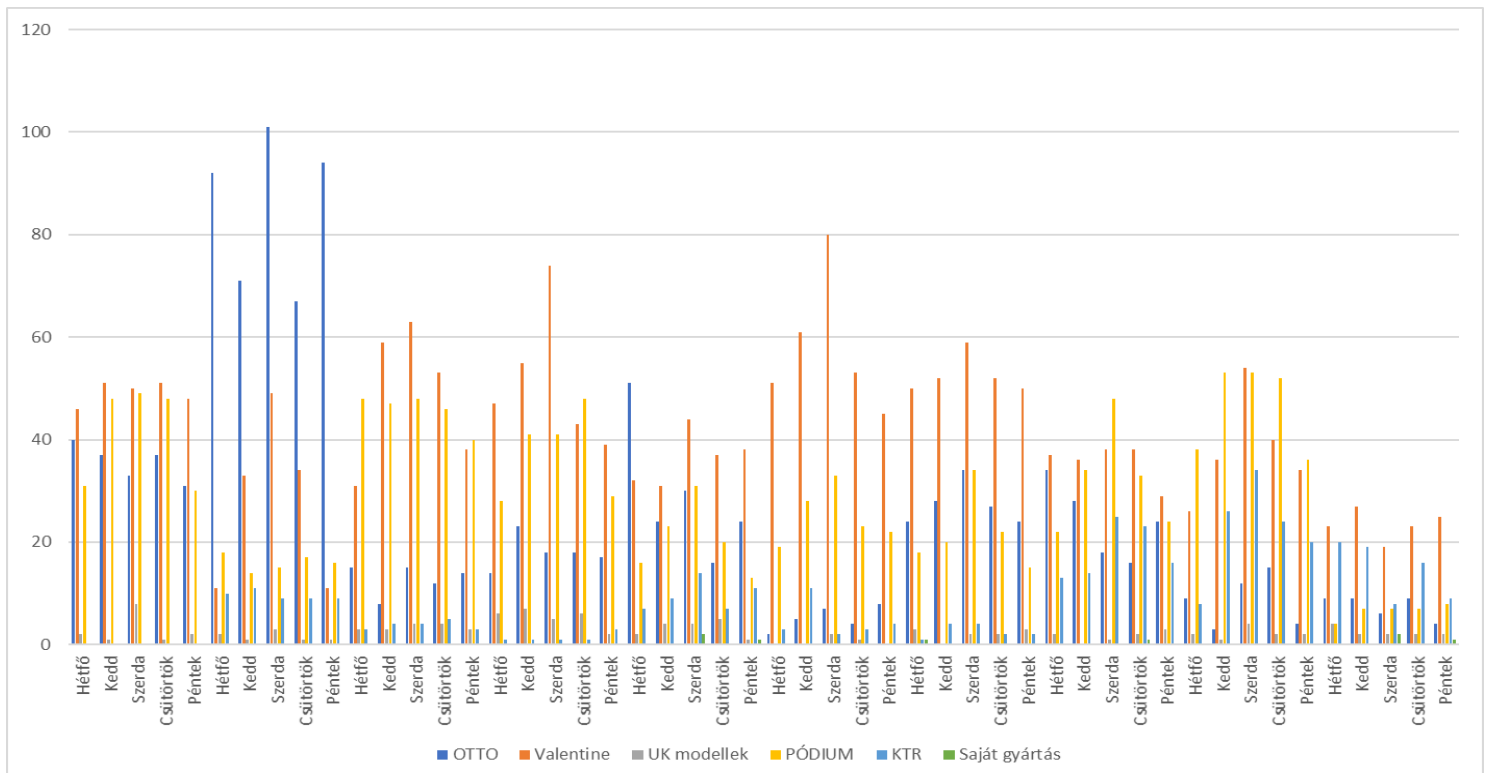

13. ábra. Utolsó rendszer feladatkiosztás számának eredménye Lista algoritmussal

A 13. ábra önmagában most nem mutat sok érdekességet. Ha a 11. ábrával összevetjük, láthatóvá válnak azok a napok, melyek a kis időszükségletű feladatokat kapták meg. Továbbá, ha a 12. ábrával is 
összevetjük, láthatóvá válik, hogy a korábbi kis időszükséglettel rendelkező feladatok során fellépő probléma nem megoldódott, hanem megváltozott. Eltérő napokra kerültek ezek a feladatok.

\subsection{Következtetés}

A fentebb bemutatott verziók fejlődése során olyan eredmények kerültek bemutatásra, melyek, ha bizonyos szempontok szerint vannak vizsgálva adnak választ. Ezen szempontok között lehetnek eltérések, amik alapján az eredmények se adhatnak kielégítő választ az adott feladatra. Emiatt igyekeztünk a lehető legtöbb magyarázatot adni, hogy látható legyen mely szemponton volt a hangsúly az eredmények közlése során.

Az utolsó verzió elérése már meglepően sok gondot okozott a rendszer fejlesztése során. Mivel egy naphoz tartozó gépek száma adott, így mindig csak azt kellett kivitelezni, hogy a gépek egymáshoz képest hogyan kerülnek feltöltésre. Ám az utolsó verzió esetén ez az összehasonlítás megtöbbszöröződött, ha a gépek számáról beszélünk, hisz egyszerre 30 gépet kezel már. Ez így önmagában még nem is lett volna nehéz, de azt is figyelembe kellett venni, hogy mekkora kapacitással rendelkeznek a gépek, amelyek már eltérők voltak a napok szerint, így a gépeket csoportokba szedve kellett kezelni. Végül még arra is figyelni kellett, hogyan oldja meg a rendszer, ha valamely nap kapacitása megtelt, de a folyamat során ez ne okozzon problémát, csak szimplán hagyja figyelmen kívül. A kapott adatok alapján a fentebb bemutatott eredményeket megfelelőnek található, mivel könnyű előre tervezhetőséget adhat. Továbbá a rendelkezésre álló feladatok folyamatosan változnak attól függően, hogy a cég milyen rendeléseket kap, így a rendszer célja nem az volt, hogy egyszeri lefutás után csak akkor használják megint, ha végeztek az eddigi feladatokkal.

A cég múködése során bemutatásra került, hogy egy specializált ember végzi ezt a feladatot, ideális esetben 10 nappal előre. Ez a rendszer ezt a folyamatot gyorsíthatja fel, mert a már rendelkezésre álló adatok alapján tud nyújtani egy olyan eredményt, - kevesebb, mint egy másodperc alatt lefut - melyet kiindulási alapnak tekintve folytatódhat a tervezés, a már emberi erőforrás által használt kommunikációs csatornák segítségével történő egyéb feltételek figyelembevételével.

\section{3. Összefoglalás}

A munkánk során betekintést kaphattunk egy bútorokat gyártó cég múködésébe. Többször voltunk már különféle cégeknél gyártáslátogatás címszó alatt, de minden alkalommal csak a felszínt mutatták be, kifejezetten ügyelve rá, hogy a negatív, vagy nem túl előnyös oldaluk fedve maradjon. Ebben az esetben viszont olyan mély szintekre tudtunk betekinteni, ahol, ha el is akarták volna fedni a hibákat, képtelenek lettek volna, mivel szembeötlő volt a feszültség bizonyos területeken, melynek oka visszavezethető valamilyen rendszerben megbúvó problémára.

A gyártás folyamatának felépítése és végig követése után nagyon érdekes felismerést okozott, hogy minden üzem legtöbb területén a feladatokat egy bejáratott szisztéma szerint végzik el. Ami a legmegdöbbentőbb volt, hogy a feladatok kiosztásának alapja végső soron nem sok szálból, hanem ezen cég esetében a termeléstervezéstől jött. Olyan szinten ehhez igazodott minden termelési folyamat, hogy nem is próbáltuk felbecsülni a kockázatelemzés eredményét abban az esetben, ha a termeléstervezést végző személy előre nem látható esemény során nem tudja elvégezni feladatát hosszabb távon. 
Sokadik nekifutás után sikerült csak olyan vázlatot készíteni, amin elindulhatott a rendszer a megvalósítás útján. A cégtől kapott adatokat fel kellett dolgozni, de egyszerre olyan soknak bizonyult, hogy csökkenteni kellett és a cél eléréséhez nem szükséges adatokat ki kellett venni a bemeneti adathalmazból. Utána a rendszernek képesnek kellett lennie ezen bemeneti adatok beolvasására és tárolására olyan szinten, hogy a rendszer minden futását követően pontosan tudjon visszaadni minden paramétert.

A rendszer jelenlegi verziója elérte a kívánt célt. Akadnak még hiányosságai, de ezen hiányosságok pótlására olyan adatokra is szükség van, melyekhez jelenleg nem férünk hozzá.

Reményeink szerint a cég belső folyamatához csatolt rendszerünk képessé válik olyan megoldásokat adni, melyek elősegítik a cég hosszú távú céljainak elérését, továbbá felfed olyan folyamatokat, melyeket ezentúl a rendszer segítségével költséghatékonyabban képesek kezelni és véghez vinni.

\section{Felhasznált irodalom}

[1] Dósa György, Imreh Csanád, Online algoritmusok, egyetemi jegyzet, Pannon Egyetem, 2011

[2] Szegedi Zoltán, Prezenszki József, Logisztika-menedzsment, Kossuth Kiadó, 2005

[3] Dr. Kardos Károly, Jósvai János, Gyártási folyamatok tervezése, egyetemi jegyzet, Széchenyi István Egyetem, Győr, 2005 